\title{
Diatoms from Mammoth Cave, Kentucky
}

\author{
By Sam L. Van Landingham ${ }^{1}$ ) \\ With 5 figures in the text
}

\section{Introduction}

At the end of the last century and continuously during World War I a special branch of biospeleology, that is, the investigation of cave floras, developed and underwent a remarkable progress in Europe. The monumental works of Lämmermayr, $(1912,1914,1916)$ dealing with the cave floras of Austria, Lampert's (1908) of Germany and that of Maheu (1906) describing the vegetation of French caves firmly established the presence of different thallophytes in the speleo-environment. Higher plants, however, were also found by these investigators and mosses, pteridophytes, and even some gymnosperms and angiosperms were reported. At the same time, on the North American Continent, phyto-speleology had a good start in the work of Call (1897). For reasons absolutely unclear, however, the pioneering work of Call has never been followed up and until the present time no paper deals with American cave floras.

Phyto-speleology also suffered a set-back in Europe between the two world wars and during this period only a few papers can be found dealing with this subject. Morton $(1925,1927)$ summarized the then current knowledge about phyto-speleology while Gams (see in Morton, 1927) started an investigation of the flora of the Alpine caves. Zmuda (see in Morton, 1927) worked on the caves of the Czech and Polish side of the Karpathian Mountains and Magdeburg (1929-1932) reported some algae from caves in the Schwäbisch-Alps. These reports, however, are quite scattered and actually, until the early 1950's, no systematic investigation of the phytocoenoses of caves has been undertaken. A new impetus to cave algal research was given by the works of Claus (1955, 1960, 1962a, 1962b, 1964), Palik (1960a, 1960b) and Suba (1957), who reported the algal floras of several Hungarian caves. At approximately the same period Friedmann (1955, 1956, 1961, 1962) started an investigation of the cave algae in Israel, while Victor

1) Department of Biology, University of Louisville, Louisville, Kentucky. 
Coumartin and the members of the Institute for Speleology in Moulis, France undertook studies of the microbial populations of caves, excluding the algae.

As was pointed out earlier no such studies have as yet been conducted in any of the caves of the United States; therefore we were glad to have this opportunity when we were asked to identify the diatoms present in the material collected in the Mammoth Cave, Kentucky.

\section{Geological and Environmental Conditions}

One of the largest cave systems in the world can be found excavated in the Kentucky karst in the south central portion of Kentucky. The Mammoth Cave, as many of the European caves, was once inhabited by Paleolithic man and has served as a shelter continuously from the 15th century, B.C., presumably for Indian tribes. Exploration of the approximately 28 miles of passages had been started at the end of the 19 th century, but the real scientific investigation of the cave did not begin until the early 20 th century. The first explorers were primarily interested in utilizing the cave for commercial purposes (growing mushrooms, excavating guano, or even medical purposes - tubercular patients were placed in the cave in the hope that the constant temperature and humidity would effect a cure).

The Mammoth Cave lies under the so called Mammoth Cave Ridge, which is part of the Mammoth Cave Plateau. It is excavated in the Mississippian limestone layers of Ste. Genèvieve and Girken of Chester and Meremac age. The limestones are covered by Big Clifty (Cypress) Sandstone which is again overlain by a layer of Haney (Golconda) Limestone.

Two underground rivers, the Echo and Styx, flow through the cave and are fed by both direct surface water inflow and by water seeping through the bedrock. Their water ultimately emerges in the Green River, which, during flood periods backs up and overruns several of the cave's passages. The direct water inflow is the result of the resistant shale layers in the Haney Limestone, which channel the water through vertical shafts into the cave. In places where the sandstone caprock has been kept intact, the water can only seep through the bedrock and will give rise to the beautiful stalactite and stalagmite formations found in the cave (Lobeck, 1929; Smith, 1964; Watson and Smith, 1963).

The speleo-environment, with the exception of relatively small caves, is characterized throughout the world by its relatively great stability. The mean annual temperature has a close correlation to that of the soil at a depth of between 50 and 100 meters. Fluctuations in 
the temperature are, except for the entrance areas, practically nonexistent, therefore in the temperate zones the thermocline of a cave is level and lies between 9.5 and $10.5^{\circ} \mathrm{C}$. Since cave systems usually arise in limestones due to its comparatively high solubility in slightly acidic water, the larger caves almost invariably have at least one underground river. Dependent upon the degree of isolation of the cave system from the surface, the underground rivers may be fed by direct surface inflows following rainfalls or may be the results of water seeping down through the bedrock. In the latter case a remarkable constancy of the water's temperature, $\mathrm{pH}$, inorganic content, and specific conductivity is observed. This constancy greatly furthers the stable environment presented by a cave. On the other hand, if direct surface water inflow occurs, which is the case in the Mammoth Cave System, great variations in all of the physical and chemical characteristics of the underground rivers can be observed, which are the direct consequences of the amount of rainfall. In such caves periodic floodings occur due to seasonal variation in the rainfall and spring thaws, making them difficult to study because of the great fluctuations of the physical and chemical factors introduced by the floods. The caves hitherto investigated both in Europe and in Israel apparently fall in the first category mentioned and the researchers did not have to face the problems introduced by such changes produced in the environment due to the periodically occurring floods. Therefore the environment modifying effect of the waters in the Mammoth Cave System has to be carefully evaluated in any future studies dealing with the ecology of cavernicole plants or animals.

Due to the more or less closed nature of a cave its atmosphere is almost constantly at 100 percent humidity, which is not even changed by the air currents which may develop in its corridors and chambers. This saturation of the atmosphere with water vapors presents an environment in which even non-aerophytes can possibly survive. Another effect of this high saturation is the sterilization of the atmosphere: small particles, such as dust, spores, pollen, etc., swept into the cave by the air currents, serve as a condensation center and are almost immediately precipitated. For this reason caves are useful as climatic resorts for patients suffering from bronchial asthma and for this same reason one can eliminate the possibility of the contamination of the interior of the caves by surface materials carried in by air currents.

Except for the immediate entrance areas there would naturally be constant and complete darkness in the cave, a fact which has been changed by the recently introduced electrical illumination. Especially during holidays, due to the great number of visitors to the cave, 
certain areas are illuminated for as long as 12 hours per day which supposedly has brought about some drastic changes in the prevailing ecological conditions. Light is a limiting factor for most of the plants and animals and the introduction of artificial illumination into a closed eco-system adopted originally to the total absence of light must have resulted in changes which are no longer possible to assess.

\section{Materials and Methods}

During the summer of 1964 six vials containing the residue of presumed algae and collected in the Mammoth Cave on August 21, 1963, by G.Claus, were sent to the author for the possible identification of diatoms in the collections. ${ }^{2}$ ). The contents of the vials consisted mostly of some kind of a dried material with the exception of Sample No. 10, which, at the time of its arrival, still contained some liquid. The materials in the bottles were of a bluish-grey or blackish color and at closer inspection one could observe quantities of sand-like or other crystalline inorganic matter in them, held together with an apparently once mucinous matrix.

According to the description given me by Claus the contents of the vials were collected under sterile conditions, using sterile instruments and the vials themselves had been pre-sterilized. The majority of the samples were the results of wall scrapings from the cave, from places where their collector had presumed the presence of algae. Sample No. 10, however, was collected with a sterile spoon from mud occurring in the small ponds on the cave's floor.

The six samples received by me had the following numbering and descriptions: No. 4. Tufts of blackish red, mucinous material on old logs. Washington's Pit Bridge; No. 8. Abundant bluish-grey, mucous growth on rock walls. Mammoth Tower; No. 10. Mud from small ponds. Corridor after Mammoth Tower; No. 11. Wall scraping of blackish, layered, corrugated material. Main Corridor; No. 12. Heavy bluish-green growth on walls around a lamp. Main Corridor; No. 12 a. Branching red growth on old log. Main Corridor.

From small portions of the contents of the vials immediately after their arrival watery preparations were made to test for the presence of diatoms and in order to establish whether the forms found contained chloroplasts. Although the scarcity of the diatoms in the preparations did not allow us to quantitatively determine their abundances these watery preparations at least could serve to establish the

2) The author wishes to express his gratitude to Dr. G. Claus for supplying this highly interesting investigational material. 
fact that the majority of the forms must have been conducting active life processes in the cave since not only empty frustules were found but, in many instances, protoplasmic remains and shrunken chloroplasts, still having their characteristic colors, could be identified.

The material obtained was rather small in quantity; therefore, considerable effort was made not to lose any during the preparation of permanent slides. The contents of the vials were processed according to standard techniques: boiled in acids, washed, dried on cover slips, and mounted in Hyrax.

The identifications were carried out with a Baush and Lomb microscope using $40 \times$, and $100 \times$ objectives and $12 \times$ oculars. The drawings were prepared from projected specimens.

\section{Taxonomy and Autecology}

In the following part the different diatom taxa identified in the samples are enumerated according to the system of Hustedt (1930a). After the name of a species its general occurrences are given, taken over from the above cited work, or, if newer data became available concerning the autecology of the forms, those data are also mentioned. One is cautioned, however, not to accept any of these statements as a final verdict concerning the environmental conditions preferred by a species, as the ecology of the diatoms is a rather controversial subject and the newer investigations, especially those of Cholnoky (1960 a, 1960 b, $1962 \mathrm{a}, 1962 \mathrm{~b}, 1962 \mathrm{c}$ ) have already produced several startling results.

The Sample No. in which the form was found is given at the end of the description, together with an estimate of its abundance. If only one specimen of a certain form was found on a slide the designation very scarce is used; if two or three, they are designated scarce; if four, they are called some; if five, they are denoted very fex ; and if above five, but not more than seven (which seemed to be the upper limit) they are referred to as $a$ few.

\section{Order: CENTRALES}

\section{Family: Coscinodiscaceae}

\section{MELOSIRA GRANULATA (Ehr.) Ralfs}

$$
\text { var. ANGUSTISSIMA, Müll. }
$$

According to the opinion of Cholnoky (1962a, 1962c), this varietas cannot be accepted as valid since a complete, unbroken form series exists between the type and it. Since, however, in my material I found only the variety and never the type, it seems as though an ecological or geographical isolation may exist between them which substantiates 
their separation. If it will later be proved that such isolation really occurs between the type and its variety, resulting in well defined own areals for the varietas, which seems to be the case in the Mammoth Cave, then the variety even should be elevated to the rank of a subspecies.

The type occurs in the plankton of eutrophic lakes, ponds, and rivers, widely distributed and often in great masses, especially during the summer. In mountainous areas it is somewhat rarer. The varietas is often encountered together with the type, but it can also be found by itself in great quantities.

Foged (1948) found the variety in a pH range of 6.4-8.3, at 5.5$18.4 \mathrm{G}^{\circ}$ hardness, in a salt concentration of $17-159 \mathrm{mg} . / \mathrm{l}$., and at $0-133 \%$ oxygen saturation. He concludes that the form is indifferent to salt, is alkalipnil and a limnobiont planktont. In his later work (Foged, 1951) M.granulata var. angustissima is described from springs with a $\mathrm{pH}$ of $7.4-7.7$, having a total hardness of $7.2-10.7 \mathrm{G}^{\circ}$, at a salt concentration of $16-24 \mathrm{mg}$./l.

According to Hustedt (1957) the presence of the variety in an environment indicates "highly eutrophic" conditions and it is alkaliphil and oligohalobic.

Cholnoky (1962 a) characterizes the species, in which he proposes to include the variety, as a euplanktonic form occurring in heavily eutrophic, slightly alkaline waters.

After these more or less concurring results it is interesting to note that Bourrelly and Manguin (1952) report the variety from sphagnetums, in a $\mathrm{pH}$ range of $3.5-6.5$, in the high mountain areas (1300$1500 \mathrm{~m}$.) of Guadeloupe.

Sample No. 12, some.

\section{MELOSIRA VARIANS Ag.}

Very common in eutrophic lakes, ponds or rivers, often littoral, cosmopolitan. If it occurs in great masses it is often considered as $\beta$-mesosaprobic.

According to Kolbe (1927) the species occurs in waters with 20$40 \mathrm{G}^{\circ}$ hardness, in a salt concentration range of $500-2000 \mathrm{mg}$./l., thus it is indifferent to salt.

Foged (1948) reports it in a $\mathrm{pH}$ range of $6.4-8.3$, at $5.5-18.4 \mathrm{G}^{\circ}$ hardness, in 17-159 mg./l. salt concentration, and at $0-180 \%$ oxygen saturation. In summarizing he states that the species is a littoral, planktonic, alkaliphil form with a preference to mineralized organic matter.

Hustedt (1938-1939), on the other hand, found the species between $\mathrm{pH} 3.0-7.8$ in materials from Java and Bali. 
According to Scheele (1952) M.varians is a littoral form both of standing and flowing waters, indifferent to current, occurring in a $\mathrm{pH}$ range of $6.8-8.2$, thus being alkaliphil, at $3.2-14.5 \mathrm{G}^{\circ}$ hardness.

Hustedt (1957), in his work on the Weser, concludes that the species is a freshwater form, oligohalobic but not sensitive to $\mathrm{Cl}^{-}$concentration since it may also show massive development at higher $\mathrm{Cl}^{-}$contents. It is cosmopolitan, abundant nearly everywhere, especially in the temperate zones. Being an euryoxybiont it often becomes saprophytic if it occurs in masses.

Sample No. 12, some.

\section{Order: PENNALES \\ Family: Fragilariaceae \\ 3. DIATOMA VULGARE Bory}

Cosmopolitan and very common in still littoral zones and especially in running water. Diatom masses found in aqueducts, wells or springs are often comprised of its pure growth.

Kolbe (1927) found the species in waters with a hardness of $40 \mathrm{G}^{\circ}$, at a salt concentration of $2000 \mathrm{mg}$./l.; thus it seems to be indifferent to salt.

According to Foged (1948) it is a rheophilous, littoral form found frequently in running waters, in a $\mathrm{pH}$ range of $6.4-8.3$, between $5.5-$ $7.1 \mathrm{G}^{\circ}$ hardness, at a salt concentration of $17-159 \mathrm{mg} . / 1$ and at $0-180 \%$ oxygen saturation.

Scheele (1952) reports it in $\mathrm{pH}$ 6.9-8.1, as being alkaliphil and salt indifferent.

Hustedt (1957) summarizes the autecology of the species in the following way: It is an alkalibiont, saproxen, oligohalobic or indifferent, littoral form, on the marginal hydrophytes of streams, rivers, ditches, in the surf zone of continental lakes; likewise tychoplanktonic but never planktonic; cosmopolitan.

The report of Fusey (1948) about the occurrence of D. vulgare in sphagnetums, at $\mathrm{pH} 6.5$ is, in view of the above enumerated statements, noteworthy.

Sample No. 12, very fex.

\section{MERIDION CIRCULARE (Gréville) Ag.}

Cosmopolitan and very common, especially in slowly flowing waters.

According to Kolbe (1927) the species occurs at pH 8.2, in waters with $20-40 \mathrm{G}^{\circ}$ hardness, and between $500-2000 \mathrm{mg}$./l. salt concentration, thus it is salt indifferent. 
Foged (1948) found it in a $\mathrm{pH}$ range of $6.4-8.3$, at $5.5-18.4 \mathrm{G}^{\circ}$ hardness with $17-159 \mathrm{mg} . / \mathrm{l}$. salt concentration and $0-180 \%$ oxygen saturation. He describes it as a typical rheobiontic, alkaliphil, salt indifferent organism.

Scheele (1952) confirms the above results stating that the species occurs between $6.3-8.2 \mathrm{pH}$, thus it is alkaliphil and at $1-52 \mathrm{mg} . \mathrm{Cl}^{-} / \mathrm{l}$. salt concentration, indicating its salt indifferent nature.

Hustedt (1957) concludes that $M$.circulare is a littoral, planktonic, rheophilic, alkaliphil, saproxen, oligohalobic form.

Foged (1955), however, reports its occurrence from lakes, pools, waterfalls, rivers, brooks, springs and soil, thus casting some doubt as to the truly rheophilic nature of it.

Sample No. 12, scarce.

\section{FRAGILARIA sp.}

Since the only specimen found was in cantal view it was impossible to identify it.

Sample No. 10. very scarce.

6. SYNEDRA ULNA (Nitzsch) Ehr. var. $O X Y R H Y N C H U S$ (Kütz.) van Heurck

Cholnoky $(1962 \mathrm{a}, 1962 \mathrm{c})$ doubts the validity of the varietas and he proposes its inclusion into the type; cf. with remark under species No. 1.

It is one of the most widely distributed diatoms and as such it occurs quite commonly in any type of water, but especially in the littoral zone of strongly eutrophic lakes or ponds. Its varieties are often mixed with the type, sometimes, however, they occur isolated. This also seems to be the case in Mammoth Cave.

The studies of Foged (1948) showed that the variety occurs at 6.6-7.9 $\mathrm{pH}$, in waters with $10.6-15.8 \mathrm{G}^{\circ}$ hardness, with $25-159 \mathrm{mg}$./l. salt concentration and 11-180\% oxygen saturation. These data indicate that it is alkaliphil and salt indifferent. In a later work Foged (1951) described the species from a $\mathrm{pH}$ range of 7.4-7.7, and he found that the variety is a littoral, markedly eurytopous cosmopolitan, indifferent to the action of the current.

Cholnoky (1962a, 1962c), who has the opinion that the validity of the variety is questionable, describes the type as a cosmopolitan inhabitant of slightly to heavily alkaline waters, occurring often in great masses. 
Bourrelly and Manguin (1952), however, found S.ulna var. oxyrhynchus at $\mathrm{pH} 4.8$, at $1420 \mathrm{~m}$. elevation in Guadeloupe.

Sample No. 10, very fex.

\section{SYNEDRA RUMPENS Kütz.}

Cosmopolitan, especially in the littoral zone of still waters, not too common.

Foged (1948), studying the ecological conditions in which the species occurs, found that a pH range of 6.8-8.3, with a hardness of 9.0$4.9 \mathrm{G}^{\circ}$, and salt concentration of $23-50 \mathrm{mg} . / \mathrm{l}$., at $36-126 \%$ oxygen saturation are advantageous for its thriving. He concludes that $S$. rumpens is a limnophilous, $\mathrm{pH}$ and salt indifferent species.

Hustedt (1937-38) writes: It is probably a cosmopolitan form but which is more frequent in warmer lands. It is oligohalobic and a fresh water species. In his later work Hustedt (1938-39) reports it from a $\mathrm{pH}$ range of $5.0-7.8$.

Cholnoky (1960a) found S.rumpens in neutral or slightly alkaline waters, and two years later $(1962 \mathrm{a})$ he states that the $\mathrm{pH}$ optimum of the species is 8.0 , or somewhat above it.

Sample No. 12, scarce.

\section{Family: Achnanthaceae}

8. ACHNANTHES MICROCEPHALA (Kütz.) Grun.

In the most different types of waters, very common, often in masses; cosmopolitan.

Cholnoky already in 1960 (b) was of the opinion that the species is not an acidobiont. In 1962 (a) he came to the conclusion that A.microcephala occurs only in neutral to slightly acidic waters with high oxygen content. The idea that it can be found in any kind of water seems to him to be incorrect. In his somewhat later work (1962c) he adds that the species is cosmopolitan and under the above mentioned conditions it can occur in great masses.

Sample No. 10, some.

\section{Family: Naviculaceae}

9. STAURONEIS sp.

Since the only specimen found was in girdle view it was impossible to identify it.

Sample No. 10, very scarce. 
10. PINNULARIA sp.

Since the only specimen found was in girdle view it was impossible to identify it.

Sample No. 10, very scarce.

\section{CYMBELLA ef. DELICATULA Kütz.}

Length $35 \mu$, width $6-8 \mu$, striae approximately 26 in $10 \mu$. This specimen compares favorable with C.delicatula Kütz.; however the length is slightly more than normal and the raphe and apices are slightly different. Fig. 1. This may be a new species.

The type is usually found on submerged rocks in mountain regions, not too scarce but in very low abundance.

In Sample No. 10, scarce.

\section{CYMBELLA PROSTRATA (Berk.) Cleve}

In the littoral zone of both fresh and slightly saline water, common and cosmopolitan.

Kolbe (1927) describes the form from waters with $20-40 \mathrm{G}^{\circ}$ hardness and with 500-2000 mg./l. salt content, therefore he thinks that it is salt indifferent.

Foged (1948) found it in a pH range of 6.4-8.3, with 5.5-15.0 G hardness and 17-145 mg./l. salt concentration, and with 20-180\% oxygen saturation, but also was able to demonstrate its presence in brackish waters with a moderate $\mathrm{Cl}^{-}$content. The species, according to him, is rheophilous.

Hustedt (1957) describes C.prostrata as a widespread, alkaliphil, oligohalobic, oligosaprobic, littoral form, frequently attached to aquatic plants.

Fusey (1948), however, reports the species from sphagnetums with a $\mathrm{pH}$ of 6.5 .

Sample No. 10, very fex.

13. CYMBELLA cf. BREHMII Hust.

Length $16 \mu$, width $6-7 \mu$, striae on dorsal side 8 in $10 \mu$, on ventral 10-12 in $10 \mu$. This specimen appears to be similar to C.brehmii Hust.; however, the resemblance is only superficial. Attention must be called to the broad, unornamented central area on both sides of the raphe. Fig. 2. It is quite possible that this form has nothing to do with $C$. brehmii Hust. and will ultimately turn out to be a new species. Further investigations, which are now in progress, are required to ascertain 
this point. If these will prove this form to be new to science its formal description will be given in a subsequent publication. For the time being, however, it seemed to be wisest to enumerate it under the above used designation.

The type is uncommon, it occurs on submerged rocks or leaves of liverworts.

According to Cholnoky (1955) it frequents acidic and possibly oligothermic waters.

Sample No. 10, scarce.

\section{CYMBELLA sp.}

Length $40 \mu$, width $16 \mu$, striae $6-8$ in $10 \mu$. This specimen does not seem to resemble any known species very closely. The broad unornamented central area on both sides of the raphe seems to distinguish it from the hitherto described forms. Fig. 3. Since up to the present only 2 specimens of it were seen, its description must await the results of further studies which are in progress. If these will prove this form to be new to science its formal description will be given in a subsequent publication.

Sample No. 10, scarce.

\section{GOMPHONEMA ef. PARVULUM (Kütz.) Grun.}

Length $16 \mu$, width $5.5 \mu$, striae in $9-10$ in $10 \mu$. This specimen appears to be similar to G.parsulum (Kütz). Grun.; however, the resemblance is mostly superficial. The presence of the broad, unornamented central area on both sides of the raphe clearly delineates it from G.parvulum (Kütz.) Grun. (Fig. 4), therefore it is quite possible that this form has nothing to do with it and ultimately will turn out to be a new species. Further investigations which are in progress, are required to clarify this problem. If these will prove the above mentioned form to be new to science its formal description will be given in a subsequent publication. For the time being, however, it seemed to be wisest to enumerate it under the above designation.

The type is cosmopolitan and often very common in still waters.

Hustedt (1957) thinks that the species is a saprophyte.

Cholnoky (1960 a) found G.parulum in neutral and alkaline, mesotrophic waters with high organic nitrogen content. In 1962 (a) he further elaborates the autecology of this form: G.parsulum is not completely $\mathrm{N}$ autotrophic therefore it very often occurs in waters in which the $\mathrm{N}$ concentration varies greatly. The species may often develop in enormous quantities in moderately or strongly alkaline 
waters which carry a high organic-N load (above $2-5 \mathrm{mg}$./l.). On the other hand it cannot tolerate much higher osmotic pressures and it undergoes a specific change of form if the $\mathrm{pH}$ value is lowered. It cannot withstand at all a $\mathrm{pH}$ below 6 . Generally it is widely distributed and probably is cosmopolitan. In his somewhat later work Cholnoky (1962c) summarizes his opinion in the following way: The species is cosmopolitan and sometimes occurs in great masses in alkaline, more or less eutrophic waters.

Sample No. 10, scarce.

\section{GOMPHONEMA LANCEOLATUM (Ehr.) var. INSIGNIS (Greg.) Cleve.}

Length $37 \mu$, width $8 \mu$, striae $12-13$ in $10 \mu$. Fig. 5 .

The type is cosmopolitan in fresh water, but occurs rather scatteredly. The varietas is usually found together with the type, sometimes, however, it exhibits greater divergences and a special, well delineated areal. Therefore, some authors think that it might represent an independent species: G.insignis Greg. Its isolated occurrence in Mammoth Cave may lend some support to this latter view.

Sample No. 10, a few.

1

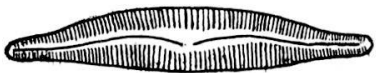
$10 u$
2

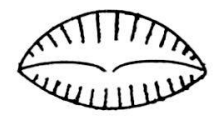

$10 u$

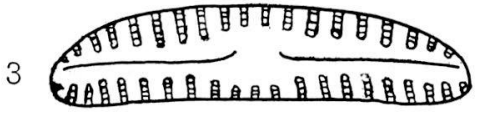

$\longmapsto 10 u$

4

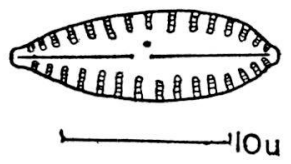

5

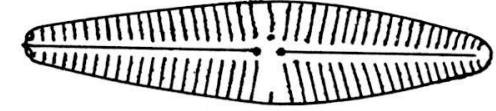

$10 u$

Fig. 1. Cymbella cf. delicatula Kütz. (possibly new species). Fig. 2. Cymbella cf. brehmii Hust. (possibly new species). Fig. 3. Cymbella sp. (possibly new species). Fig. 4. Gomphonema cf. parvulum (Kütz.) Grun. (possibly new species). Fig. 5. Gomphonema lanceolatum (Ehr.) var. insignis (Greg.) Cleve. 


\section{Discussion}

The investigations resulted in the determination of 16 different diatom taxa which are enumerated in Table 1. Their habitat in the cave is also indicated. One should call attention to the fact that out of the six samples investigated only two were found to contain diatoms, samples No. 10 and 12. It is easy to understand that a sample (No.10) which originated from small ponds and pond mud collected

Table 1

Diatom Occurrences in Mammoth Cave

\begin{tabular}{|c|c|c|}
\hline \multirow{2}{*}{ Name of Organism } & \multicolumn{2}{|c|}{ Sample No. } \\
\hline & 10 & 12 \\
\hline Achnanthes microcephala (Kutz) Grun. & + & \\
\hline Cymbella cf. brehmii Hust (possibly new) & + & \\
\hline Cymbella cf. delicatula Kutz (possibly new) & + & \\
\hline Cymbella prostrata (Berkl.) Cleve & + & \\
\hline Cymbella sp. (possibly new) & + & \\
\hline Diatoma vulgare Bory & + & \\
\hline Fragilaria sp. (cantal view)* & + & \\
\hline Gomphonema lanceolatum (Ehr.) var. insignis (Greg.) Cleve* & + & \\
\hline Gomphonema cf. parsulum (Kutz) Grun. (possibly new) & + & \\
\hline Melosira granulata (Ehr.) Pralfs var. angustissima Mull. & & + \\
\hline Melosira varians $\mathrm{Ag}$. & & + \\
\hline Meridion circulare (Gréville) Ag. & & + \\
\hline Pinnularia sp. (girdle view)* & + & \\
\hline Stauroneis sp. (girdle view)* & + & \\
\hline Synedra rumpens Kutz & & + \\
\hline $\begin{array}{l}\text { Synedra ulna (Nitzsch) Ehr. var. oxyrhynchus (Kutz) } \\
\text { van Heurck }\end{array}$ & + & \\
\hline Total: 16 taxa & 12 & 4 \\
\hline
\end{tabular}

Forms marked with * were not seen in the "fresh preparations".

with a spoon would contain quite a large number of different Bacillariophyta. This sample which made up a rather interesting and unusual assemblage, had 12 different taxa, of which at least four are probably new to science; however, further investigations are required to conclusively prove this point. The other sample that contained diatoms (No. 12) originated from wall scrapings which were growing around a lamp. The four taxa found in Sample No. 12 may well have been autotrophs, deriving their source of energy from the lamp. An interesting fact, however, is that in this sample, where 
one would imagine that because of the illumination the ecologically limiting factors were more favorable for diatom growth, only four species were present, in contrast to Sample No. 10, which received no illumination whatsoever.

No diatoms were found in the other samples, which is rather surprising. One would especially expect their presence in Samples Nos. 4 and $12 \mathrm{a}$ where the collected material came from old logs. Since several auxotrophic or even heterotrophic diatoms are known it would have been natural to find at least some species which are able to derive their nutritional requirements from the rotten wood growing in these habitats and it is hard to understand why diatoms did not occur in these places. The two habitats in which diatom communities were found vary widely in their microenvironment. One of them represents small ponds where benthic or partially tychoplanktonic communities could develop while the other, representing the wall scrapings, should show forms adapted to more or less aerial habitats. Since there is such a wide discrepancy between the ecological factors prevailing in the two habitats, it is not surprising that not a single specimen was found to be common to both of them. The case is, however, somewhat complicated by the fact that in the material collected from the wall of the cave, three out of the four species are definitely planktonic forms, although more commonly reported from the littoral zone. One may speculate about the significance of this finding; however, further studies are required to establish any definite results in this connection.

If one compares the diatom distribution of Mammoth Cave with the distribution reported from other caves some similarities will become apparent. In most of the caves investigated up to the present the occurrence of a certain species was restricted to just one or two localities in the cave, indicating that the vast majority of the samplings had their own algal community resulting from possible differences in the microenvironmental conditions of each given habitat. The only exception to this statement is represented by the occurrence of Eunotia trinacria Krasske reported by Claus (1962a) from 8 samples out of a total of 19 collected in the relatively small cave of Abiliget. This exception might be due to the small size of the investigated cave, where transportation of the species and the less well defined microhabitats might have furthered a wider distribution of E.trinacria in the cave. In all the other caves studied, possibly because of their dimensions, a better separation of the localities occurred, which helped in isolating the communities of these different habitats.

From the section describing the different species found in the Mammoth Cave it becomes clear that none of the species occurred with 
any considerable abundance in the samples. From this point of view one cannot attempt any comparison with the diatom communities investigated in other caves, especially since all of the previous reports were based on the results of cultured material, which naturally do not represent the original abundances of the species. In this study no cultures were attempted as the intention was to ascertain the original numbers of diatoms in a given habitat. The scarcity of the specimens found might be due to one or many factors as pointed out by Claus (1955), who stated that culturing experiments were actually necessary in order to recognize the algal community of a cave since comparatively large areas may have contained only one or a few specimens, which could easily be overlooked in direct microscopic examination, thus yielding inaccurate results, a statement which certainly seems to be true for the diatom community of Mammoth Cave. On the other hand, besides the ecologically limiting factors, such as lack of light, lack of organic material useful for auxotrophic growth, etc., one may add the fact that these diatoms, which seem to be primary producers, may be used up in the food chain of lower invertebrates, thus making their appearance even more scarce.

Since, as it was mentioned in the paragraphs dealing with materials and methods, the samples were divided after their arrival immediately into two portions, one of which served as a "fresh preparation" in order to ascertain the presence or absence of chloroplasts in the specimen, and it was found (see Table 1) that only four out of the 16 taxa identified were not observed in these "fresh preparations" and that the other twelve forms were seen to have well developed chloroplasts, a fact which gives further indication that the diatoms collected in the caves were, if not surely autotrophic, then at least auxotrophic species. Heterotrophy in this case may quite well be ruled out since all the known heterotrophic diatom species either possess no chloroplasts or their chloroplasts occur almost completely in a decolorized form.

The fact that at least one portion of the diatom community seemed able to retain its assimilatory pigments may indicate that the diatoms have only lately become inhabitants of the cave, perhaps having been swept in recently by water currents. This assumption is further corroborated by the presence of the few euplanktonic forms found especially in the wall community. It was mentioned earlier that the levels of the underground waters of the cave undergo tremendous seasonal variations during the spring flood periods. Large portions of the cave might become completely flooded with water sweeping in planktonic forms from the surface. After the abating of the high waters, some of these 
planktonic forms could be deposited on the cave's walls, there vegetating for a while in the ecological conditions presented by the new aerial environment. These planktonic forms may be able to withstand and live through considerable periods of such a new environment as that presented by the rock walls of the cave due to the constant $100 \%$ relative humidity of the cave's atmosphere. Although these forms are limited in their motions by having been deposited on solid surfaces there is no other basic difference between a watery environment and an aerial environment affording constant $100 \%$ humidity, with the sole exception of the lack of motion of the water (currents, waves, etc.). These movements, however, are not primary factors affecting the lives of such planktonic diatoms as were found in the cave, since the planktonic forms identified in this study are generally the inhabitants of still waters and many of them occur in the littoral zones, in habitats upon which the movements of the water naturally do not exert any profound effect.

The diatom community which was found in the pools of the cave's floor seems to be a self-contained community (large numbers of different species) and therefore cannot be considered a recently acquired occupant of the cave. The autecology of the forms found in the pond communities clearly indicates that only such species occurred there that had already adapted themselves to a neutral - slightly alkaline, well oxygenated and meso to eutrophic condition. The low number of specimens found, unfortunately does not allow the carrying out of a Thomasson's analysis (1925) in order to determine the exact ecological conditions of the particular habitat, but in spite of this, the fact that not a single species was found in the above mentioned community which shows an ecological demand different from that exhibited by the majority of the species indicates that the small ponds are populated by diatoms particularly adapted to this environment. If this is the case, one may come to the conclusion that the diatom flora of the pond must have undergone periods of adaptive processes and could not have become established in only recent times. Another clue to this supposition can be found in the occurrence of the four, possibly new, species in this habitat. If all four of these forms will, indeed, prove to be new to science, one has to decide whether or not these forms are the product of the special cave environment or are derived from an as yet not well understood surface flora. In this connection it seems interesting to point out that two the Cymbela species, which might be new, and also Gomphonema cf.parsulum, had an unusually broadened and ornamented central area, which clearly distinguishes these forms from the types to which they show the closest affinity. 
The development of such broad central areas in three distinct and not very closely related species may or may not be due to the specific environmental factors afforded by the cave. Therefore one may state that the diatom flora of the Mammoth Cave, which is only partially known, already exhibits features which make it difficult to believe that such a flora was only recently derived from a surface diatom community. It is much more logical to suppose, as has been favored by Claus (loc. citt.), Palik (loc. citt.), and Suba (loc. citt.) in the cases of other caves, that the diatom flora of the Mammoth Cave is the result of an ancient community, which has undergone specific adaptations to the subterranean habitats during the course of geologic time, and is not derived from the present surface flora, but has been in the cave and has thrived there since the time of the cave's formation.

Although the study of the diatom flora of Mammoth Cave is still relatively incomplete one may make some comparisons to the floras reported from other caves. In Table 2 all of the Bacillariophyta reported from different caves are compiled. One may see that the numbers of species common to the varied troglobitic habitats are almost non-existant. Caves lying either close to each other like Baradla and Peace, or separated by thousands of miles, like Abaliget and Mammoth, have but one or two species in common. It is unfortunate that no comparison can be made between the caves of Israel investigated by Friedmann (1962) and the other known cave floras. Unfortunately, Friedmann does not enumerate the different diatom species found by him and only mentions their presence as "diatoms". The lack of common occurrences among the cavernicole diatoms in the caves of Hungary and the similar lack of occurrences between the previously mentioned caves and the Mammoth Cave would give good support to the ideas of the previously mentioned authors and also further our own conclusion that each cave has its own diatom population, which is specific for it and is entirely different from that occurring either on the surface or in other caves. This supposition, however, inevitably leads to the conclusion that the diatom communities of the caves cannot have had their origin in present or recent times, but must have been derived from such surface communities which existed at the time of the cave's formation, showing an autochthonous existence and development.

The fact that the two samples in which the presence of diatoms could definitely be ascertained without any prior culturing contained 16 different taxa, shows that the diatom community of the Mammoth Cave must be a well developed and diversified one. From this point of view the cave does not differ from the other caves investigated thus 
Table 2. Diatoms Reported from Different Caves

\begin{tabular}{|c|c|c|c|c|c|c|c|c|}
\hline \multirow[t]{2}{*}{ Name of Organism } & $\stackrel{\stackrel{0}{0}}{\frac{3}{3}}$ & 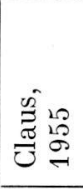 & 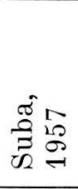 & 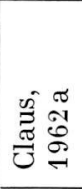 & 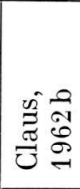 & 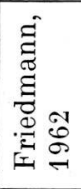 & 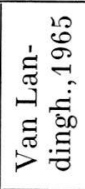 & \multirow{2}{*}{ 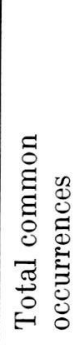 } \\
\hline & 艺 & $\begin{array}{l}\frac{\pi}{\tilde{乛}} \\
\tilde{\pi} \\
\tilde{ే}\end{array}$ & $\begin{array}{l}\frac{0}{00} \\
\frac{0}{20} \\
0\end{array}$ & 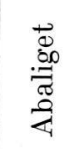 & 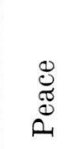 & 苞 & 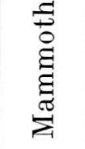 & \\
\hline $\begin{array}{l}\text { Achnanthes microcephala (Kütz.) Grun. } \\
\text { Amphora ovalis Kütz. var. pediculus Kütz. } \\
\text { Caloneis silicula (Ehr.) Cleve var. truncata Grun. } \\
\text { Caloneis zachariasi Reich. } \\
\text { Cymbella cf. brehmii Hust. (possibly new) } \\
\text { Cymbella cf. delicatula Kütz. (possibly new) } \\
\text { Cymbella prostrata (Berkl.) Cleve } \\
\text { Cymbella sp. (possibly new) } \\
\text { Diatoma elongatum Ag. var. minor Grun. } \\
\text { Diatoma vulgare Bory } \\
\text { Diatoms* } \\
\text { Eunotia arcus Ehr. } \\
\text { Eunotia lunaris (Ehr.) Grun. var. subarcuata (Naeg.) Grun. } \\
\text { Eunotica trinacria Krasske } \\
\text { Fragilaria brevistriata Grun. } \\
\text { Fragilaria construens (Ehr.) Grun. var. venter (Ehr.) Grun. } \\
\text { Fragilaria virescens Ralfs } \\
\text { Fragilaria } \text { sp. (cantal view) }\end{array}$ & & $\begin{array}{l}+ \\
+\end{array}$ & & $\begin{array}{l}+ \\
+ \\
+ \\
+\end{array}$ & & + & $\begin{array}{l}+ \\
+ \\
+ \\
+ \\
+\end{array}$ & $\begin{array}{l}1 \\
2 \\
1 \\
1 \\
1 \\
1 \\
1 \\
1 \\
1 \\
2 \\
1 \\
1 \\
1 \\
1 \\
1 \\
1 \\
1 \\
1\end{array}$ \\
\hline
\end{tabular}


Gomphonema angustatum (Kütz.) Rabenh.

Gomphonema bohemicum Reichelt et Fricke

Gomphonema gracile Ehr.

Gomphonema lanceolatum Ehr. var. insignis (Greg.) Cleve

Gomphonema parsulum (Kütz.) Grun.

Gomphonema cf. parsulum (Kütz.) Grun. (possibly new)

Hantzschia amphioxys (Ehr.) Grun.

Melosira granulata (Ehr.) Ralfs var. angustissima Müll.

Melosira varians Ag.

Meridion circulare (Gréville) Ag.

Navicula confervacea Kütz.

Nasicula minima Grun.

Navicula mutica Kütz. var. niøalis Kütz.

Navicula occulta Krasske

Navicula schonfeldii Hust.

Navicula sp. (possibly new)

Nitzschia angustata (W. Smith) Grun.

Nitzschia epithemoides Grun.

Nitzschia palea (Kütz.) W. Smith

Nitzschia thermalis Kütz. var. minor Hilse

Pinnularia gibba Ehr.

Pinnularia sp. (girdle view)

Stauroneis sp. (girdle view)

Stephanodiscus hantzschii Grun.

Synedra pulchella Kütz. var. naviculacea Grun.

Synedra rumpens Kütz.

Synedra ulna (Nitzsch) Ehr. var. oxyrhynchus (Kütz.) van Heurck

Total: 45 taxa

* Mentioned only, without taxonomical treatment.

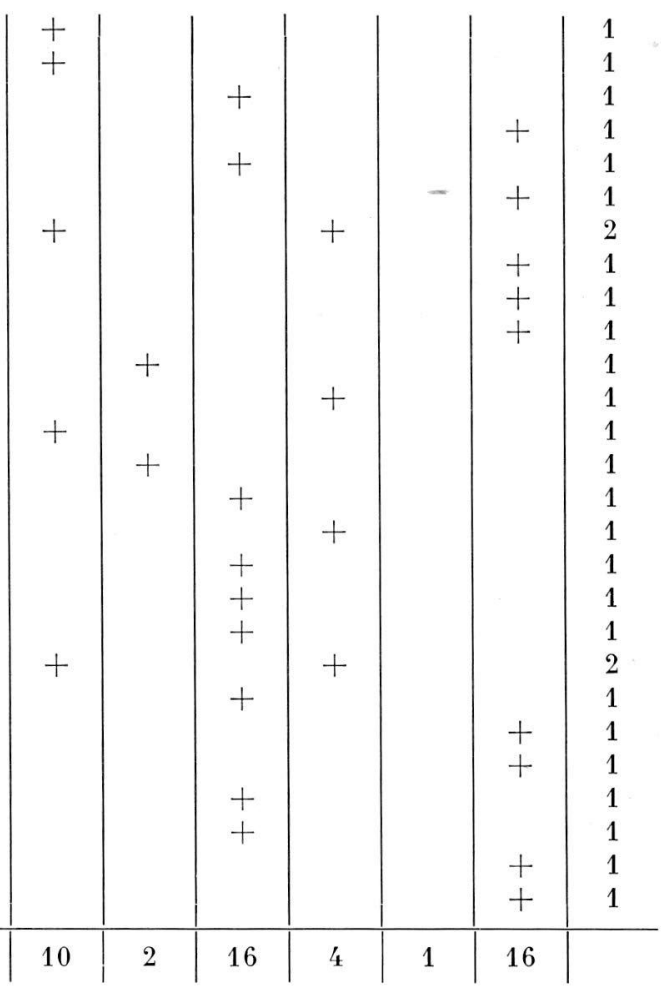


far. Exceptions, naturally, occur; thus from Peace Cave Claus (1962 b) reported only four species and in the cave of Pálvölgy (Suba, 1957) only two diatoms were found. Both of these authors, however, emphasize the fact that their papers have a more or less preliminary character and that further investigations undoubtedly will result in a great increase in the diversity and numbers of algal species found in these caves. From this point of view Sample No. 12, obtained in Mammoth Cave, is quite instructive since no data exists in the literature in which 12 different taxa are reported from a single troglobitic habitat. This, however, does not mean that when further investigations are conducted in other caves one will not come up with similar results. It is quite possible that the diversity of species found in the mentioned sample is due to the method of collection, which is different from that used previously. From the above considerations it is also clear that our work also has only a preliminary character. If two samples produced 16 different taxa there must be a great many more taxa to be found in other habitats of the cave. Thus it is most desirable to continue this type of investigation of the algal floras of the caves in order to gain a better understanding of the cave algal communities. It seems to be quite necessary to also conduct culturing experiments along with the direct microscopic investigations in order to find those species of rare occurrence which may be present in few numbers in the samples. Since no culturing has been employed in the present investigation it is easy to understand why the other 4 investigated samples appeared devoid of diatoms.

In summarizing our results we can come to the following conclusions: 1 . An autochthonous diatom community with a diversified species distribution occurs in Mammoth Cave. 2. This diatom community has such peculiarities on the basis of which it cannot be derived from the present diatom flora of the surface, but seems to be a derivative of a more ancient type of vegetation which probably has been in the cave since near the time of its formation. 3 . The greatest majority of the specimens found had well developed chloroplasts indicating that they are either autotrophic or auxotrophic, but very possibly not heterotrophic. Since the above enumerated three conclusions were reached by all the previous authors who dealt with the investigations of the algal floras of caves one may state that the diatom flora of Mammoth Cave does not differ, except for its composition, in any basic feature from the floras reported for other caves. 


\section{SUMMARY}

Samples collected in Mammoth Cave, Kentucky, revealed the presence of a diversified but not too abundant Diatom community in the cave. As the material was not subjected to culturing experiments but was investigated immediately after arrival, both in native and permanent preparations, it was possible to: 1 . ascertain that the majority of the diatoms contained well developed, apparently healthy and functioning chloroplasts and 2. to get a rough estimate of the actual number of specimens present in a microhabitat.

The identifications resulted in the recognition of $\mathbf{1 6}$ diatom taxa of which possibly 4 are new to science. Further studies are, however, required to ascertain this point.

\section{ZUSAMMENFASSUNG}

Proben aus der Mammoth-Höhle (Kentucky) zeigten, daß eine verschiedene, aber nicht sehr abundante Diatomeen-Population in dieser Höhle lebt. Da das Material nicht kultiviert, sondern sofort nach seinem Eintreffen sowohl nativ als auch in Form von Dauerpräparaten untersucht wurde, konnte man feststellen: 1. Die Mehrzahl der Diatomeen enthielt gut entwickelte, offensichtlich gesunde und funktionsfähige Chloroplasten, und 2. konnte eine annähernde Schätzung der vorkommenden Individuen erreicht werden.

Die Bestimmungen ergaben 16 Diatomeen-Taxa, von denen 4 möglicherweise neu für die Wissenschaft sind. Doch benötigt diese Frage noch weiterer Untersuchungen.

\section{REFERENCES}

Bourrelly, P. and Manguin, E. (1952) - Algues d'eau douce de la Guadeloupe et Dépendances recueillies par la Mission P.Allorge en 1936. Soc. Ed. Enseign. Sup.: 1-139. Paris.

CALl, E. R. (1897) - Some Notes on the Flora and Fauna of Mammoth Cave, Kentucky. Am. Nat. 31: 377-392.

Choln окт, B. J. (1955) - Diatomeengesellschaften aus den Donauauen oberhalb von Wien. Verh. Zool.-Bot. Ges. Wien. 95: 76-87.

- (1960a) - Beiträge zur Kenntnis der Ökologie der Diatomeen in dem Swartkops-Bache nahe Port Elizabeth (Südost-Kaapland). Hydrobiologia 16: 229-287.

- $(1960$ b $)$ - Beiträge zur Kenntnis der Diatomeenflora von Natal. Nova Hedwigia 2: 1-128.

- (1962 a) - Beiträge zur Kenntnis der Ökologie der Diatomeen in OstTransvaal. Hydrobiologia 19: 57-119.

- (1962 b) - Ein Beitrag zu der Ökologie der Diatomeen in dem englischen Protektorat Swaziland. Hydrobiologia 20:309-355.

- (1962 c) - Beiträge zur Kenntnis der Südafrikanischen Diatomeenflora III. Diatomeen aus der Kaap-provinz. Rev. Biol. 3: 1-80.

Claus, G. (1955) - Algae and Their Mode of Life in the Baradla Cave at Aggtelek. Acta Bot. Acad. Sci. Hung. 2: 1-26.

- (1960) - Re-evaluation of the Genus Gomontiella. Rev. Algol. Nouv. Ser. 5: 103-111. 
Claus, G. (1962a) - Beiträge zur Kenntnis der Algenflora der Abaligeter Höhle. Hydrobiologia 19: 192-222.

- (1962b) - Data on the Ecology of the Algae of Peace Cave in Hungary. Nova Hedwigia 4: 55-79.

- (1964) - Algae and Their Mode of Life in the Baradla Cave at Aggtelek. Part II. Internatl. J. Speleol. 1(1): 13-17.

Foged, N. (1948) - Diatoms in Water-courses in Funen. VI. Conclusions and General Remarks. Dansk. Bot. Ark. 12:1-110.

- (1951) - The Diatom Flora of Some Danish Springs. Part I. Natura Jutlandica 4: 7-84.

- (1953a) - The Distribution of Fresh Water Diatoms in Norway. A Preliminary Report. Nytt Mag. Bot. 1: 107-123.

- $(1953 \mathrm{~b})$ - Diatoms from West Greenland. Medd. Grnland 147: 1086.

- (1955) - Diatoms from Peary Land, North Greenland. Medd. Grnland 128: 1-90.

Friedmann, I. (1955) - Geitleria calcarea n. gen. and n. sp. A New Atmophytic Lime-incrusting Blue-green Alga. Bot. Not. 108: 439-445.

- (1956) - Beiträge zur Morphologie und Formwechsel der atmophytischen Bangioidee Phragmonena sordidum Zopf. Österr. Bot. Zeitschr. 103: 613-633.

- (1961) - Chroococcidiopsis kashaii sp. n. and the Genus Chroococcidiopsis. Österr. Bot. Zeitschr. 108: 354-367.

- (1962) - The Ecology of the Atmophytic Nitrate-Alga Chroococcidiopsis kashaii Friedmann. Arch. Mikrobiol. 42: 42-45.

Fusey, M. P. (1948) - Contribution à la flore algologique du Jura. I. Florule algologique de la tourbière de Frasne (Doubs). Part 1. Rev. Gen. Bot. $55: 338-426$.

Hustedt, F. (1930a) - Bacillariophyta. In: Pascher's Süßwasserflora... 10:1-462. G. Fischer, Jena.

— (1930b) - Kieselalgen. In: Rabenhorst's Kryptogamenflora... \%: 1-920. Akad. Verlag, Leipzig.

- (1937-1938) - Systematische und ökologische Untersuchungen über die Diatomeen-Flora von Java, Bali und Sumatra. Arch. Hydrobiol. Suppl. 15., No. 1.: 131-177; No. 2.: 187-295; No. 3.: 393-506; No. 4.: $638-790$.

- (1938-1939) - Systematische und ökologische Untersuchungen über die Diatomeen-Flora von Java, Bali und Sumatra. Arch. Hydrobiol. Suppl. 16., No. 1.: 1-155; No. 2.: 274-381.

- (1957) - Die Diatomeenflora des Flußsystems der Weser im Gebiet der Hansestadt Bremen. Abh. naturw. Ver. Bremen 34: 181-440.

Kolbe, R. W. (1927) - Zur Ökologie, Morphologie und Systematik der Brackwasser Diatomeen. Die Kieselalgen des Sperenberger Salzgebietes. Pflanzenforsch. 7: 1-146.

Lämmermayr, L. (1912) - Die grüne Pflanzenwelt der Höhlen. I. Teil. Denkschr. Kaiser. Akad. Wiss. Math.-Naturwiss. Kl. 87: 325-364.

- (1914) - Die grüne Pflanzenwelt der Höhlen. I. Teil. Denkschr. Kaiser. Akad. Wiss. Math.-Naturwiss. Kl. 90:125-153.

- (1916) - Die grüne Pflanzenwelt der Höhlen. I. Teil. Denkschr. Kaiser. Akad. Wiss. Math.-Naturwiss. Kl. 92: 107-148.

Lampert, K. (1908) - Tiere und Pflanzen der Jetztzeit in den schwäbischen Höhlen. Mitt. Kgl. Natur. Kabinett Stuttgart (60) : 1-39. 
Loвеск, A. K. (1929) - The Geology and Physics of the Mammoth Cave National Park, Kentucky. Kentucky Geol. Surv. Ser. 6 (31) : 327-399. Magdeburg, P. (1929-1932) - Organogene Kalkkonkretionen in Höhlen. Sitzungsber. Nat. Ges. Leipzig 59: 14-26.

Maнeu, M. J. (1906) - Contribution à l'etude de la flore souterraine de France. Ann. Sci. Nat. Sér. 9. 3: 1-189.

Morton, F. (1925) - Höhlenpflanzen. Speleol. Monogr. 5: 1-16. Publ. von Kyrle, Wien.

- (1927) - Ökologie der assimilierenden Höhlenpflanzen. In : Abderhalden's Fortschritte natur. wiss. Forsch. 12:324, Wien-Berlin.

Palik, P. (1960a) - Study into the Algal Flora of Caves. Hidrol. Közl. $40: 417-422$.

- $(1960 \mathrm{~b})$ - A New Blue-green Alga from the Cave Baradla near Aggtelek. Ann. Univ. Sci. Budapestiensis R. Eötvös nom. 3: 275-285.

SCHEele, M. (1952) - Systematische ökologische Untersuchungen über die Diatomeenflora der Fulda. Arch. Hydrobiol. 46:305-423.

Sмгтн, P. M. (1964) - The Flint Ridge Cave System: 1957-1962. Bull. Natl. Speleol. Soc. 26:17-27.

Suba, E. (1957) - Die Algen der Pálvölgyer Höhle in Ungarn. Verhandl. Zool.-Bot. Ges. Wien 97: 97-109.

Тномasson, K. (1925) - Methoden zur Untersuchung der Mikrophyten der limnischen Litoral- und Profundalzone. In: Abderhalden's Handbuch biol. Arbeitsmethoden. 9(2), Berlin.

Watson, R. A., and Sмгтн, P. M. (1963) - The Mammoth Cave National Park Research Center. : 1-50. Cave Res. Found., Yellow Springs, Ohio. 